\title{
Does the South African stock market value independent dual board leadership structure?
}

\author{
Collins G. Ntim* \\ Accounting and Finance, Business School, University of Glasgow, UK
}

Received: 25 February 2012

Revised: 28 March 2012

Accepted: 9 April 2012

\begin{abstract}
We examine the crucial policy question of whether the South African (SA) stock market values a dual board leadership structure (DBLS) using a sample of 169 listed firms from 2002 to 2007. We find a significant positive link between DBLS and market valuation, but only in firms with independent chairpersons, implying that the market values firms with independent DBLS more highly. Our results are robust across a number of econometric models that control for different types of market valuation proxies and endogeneity problems. Our findings offer empirical support for agency theory, which suggests that independent DBLS increases the capacity of the board to effectively advise, monitor and discipline top management, and thereby improving market valuation.
\end{abstract}

Keywords: corporate governance, independent dual board leadership structure, market valuation, king reports, South Africa, endogeneity

JEL Classification Codes: G12, G34, G38

\section{Introduction}

This paper sets out to investigate the crucial policy question of whether the South African (SA) stock market values dual board leadership structure (DBLS). SA has carried out corporate governance (CG) reforms, primarily in the form of the 1994 (King I) and 2002 (King II) King Reports. The King Reports have generally focused on enhancing CG standards in SA (Ntim, 2011, 2012). More specifically, however, the reforms have focused on enhancing market value by improving the ability of corporate boards to

\footnotetext{
*E-mail: collins.ntim@glasgow.ac.uk.

Citation: Ntim, C.G. (2012) Does the South African stock market value independent dual board leadership structure?, Economics and Business Letters, 1(1), 35-45.
} 
effectively advise, monitor and discipline top management (Ntim et al., 2011, 2012). A crucial proxy for corporate boards' independence, monitoring and disciplining capacity is the degree to which board leadership and power is either distributed or concentrated in one person (Lipton and Lorsch, 1992; Jensen, 1993). Corporate leadership structure typically consists of a chairman and chief executive officer (CEO). The chairman of the board is responsible for managing the board. These may typically include nominating new board members, reviewing the performance of senior management, setting agenda for board meetings, and settling conflicts which may arise within the board (Laing and Weir, 1999). In contrast, the CEO is responsible for the day-to-day management of the company, including implementing board decisions. A $D B L S$, therefore, exists when the roles of chairman and CEO are performed by different persons.

SA provides an interesting context to examine the association between $D B L S$ and firm valuation. Similar to other Anglo-American countries, SA has pursued CG reforms in the form of King I and II. King II states explicitly that the positions of the chairman and the CEO should not be held by the same individual, suggesting that it recognises CEO duality as an undesirable development, while $D B L S$ is seen as good CG practice. Therefore, this paper seeks to examine the link between $D B L S$ and market valuation for SA firms, and thereby making a number of new contributions to the extant literature. First, using a sample of 169 SA listed firms from 2002 to 2007, we provide evidence on the impact of $D B L S$ on market valuation. This represents one of the first attempts at quantifying the effect of $D B L S$ on market valuation within a Sub-Saharan African context, with specific focus on SA, and hence crucially extends the literature to that sub-continent. This also contributes to the predominantly developed countries-based literature on the association between $D B L S$ and market valuation. Second, we innovatively show that $D B L S$ impacts positively on market valuation only in firms with independent chairpersons. Finally, and unique from past studies, we employ econometric models that adequately control for different types of market valuation proxies and endogeneity problems.

The remainder of the paper is organised as follows. Section 2 provides a brief overview of the CG reforms that have been carried out and the SA corporate context. Section 3 reviews the prior theoretical and empirical literature on the impact of DBLS on market valuation. Section 4 describes the data. Section 5 reports empirical analyses, while section 6 concludes.

\section{Corporate Governance Policy Reforms, DBLS and the SA Corporate Context}

There is a general agreement that the introduction of the King Reports formally institutionalised CG practices in SA (Ntim et al., 2012). This started with the publication of the first King Report (King I) in 1994 (King Committee, 2002; Ntim et al., 2011). The suggestions of King I were heavily informed by those of the UK's Cadbury Report of 1992 (Ntim and Osei, 2011). For example, and similar to the Cadbury Report, King I proposed an Anglo-American style unitary board of directors, consisting of executive and non-executive directors, operating within a voluntary compliance CG regime (King Committee, 2002). With specific reference to having a DBLS, and similar to the Cadbury Report, it highlighted its role in ensuring that power is not concentrated in one person (King Committee, 1994). However, and distinct from the Cadbury Report, which explicitly defined the criteria for independence, King I did not clearly define who 
constitutes an independent director (Ntim, 2009). Further, and unlike Cadbury, it merely recommended that the roles of CEO and chairperson should be split, but was silent as to whether the chairperson should additionally be independent of management. That is, and crucially, King I was unable to explicitly recommend that SA corporate boards should be chaired by independent directors (King Committee, 2002; Ntim, 2011). Arguably, these deviations from the Cadbury Report impaired the effectiveness of a DBLS under King I (King Committee, 2002; Ntim et al., 2011).

Consequently, King I was revised and replaced with a second King Report (King II) in 2002 with the objective of addressing some of the limitations of King I. King II suggested two main changes with specific reference to $D B L S$. First, it provided a clear definition of independence and explicitly classified directors into executive, non-executive and independent non-executive directors (King Committee, 2002; Ntim, 2009). Second, and most critically, to make sure that there is a balance of power and authority in corporate leadership and decision-making, King II did not only recommend that SA companies should have a $D B L S$, but also the chairman of the board should additionally be an independent non-executive director (King Committee, 2002). Arguably, this enhanced the independence and monitoring capacity of having a DBLS under King II than King I.

However, the SA corporate setting is distinctively characterised by greater block and institutional ownerships, primarily in the shape of pyramidical structures and complex cross-shareholdings, but the enforcement of corporate regulations and shareholder activism are noticeably weak (Ntim et al., 2011). As a result, critical issues have been raised as to whether, given the SA corporate context, a voluntary compliance CG framework like King II will be effective in enhancing CG standards in the form of providing appropriate checks and balances with respect to top management power, monitoring, disciplining, advising and decision-making. Thus, the main aim of this paper is to investigate whether the proposals contained in the King Reports relating to $D B L S$ have any effect on market valuation in SA.

\section{The Theoretical and Empirical Literature on DBLS and Market Valuation}

Although a DBLS is conceptually viewed as a positive CG development (Ntim, 2009; Ntim and Osei, 2011), there are conflicting theoretical predictions as to its impact on market value. On the one hand, agency theory suggests that separating the two roles can help increase board independence by providing effective checks and balances over managerial behaviour (Lipton and Lorsch, 1992). It has been suggested, for example, that separating the two roles will make it easier for the board to remove a non-performing CEO (Jensen, 1993), which may improve market value. On the other hand, stewardship and resource dependence theories suggest that combining the two positions (i.e., role/CEO duality) can rather have a positive impact on market value. First, Weir et al. (2002) contend that as an insider, the CEO tend to have greater knowledge, understanding and experience of the strategic challenges and opportunities, which the company faces, than a non-executive chairman that can enhance market value. Second, it has been argued that role duality grants a charismatic CEO the opportunity to have a sharper focus on firm objectives (Ntim, 2009), which can lead to improved valuation due to the rapid management decision-making that arises from the provision of clear and unambiguous corporate leadership. Third, Vafeas and Theodorou (1998) suggest that CEO duality 
avoids extra compensation to the chairman, which can result in a reduction in managerial remuneration. Finally, Bozec (2005) argues that unified firm leadership often associated with CEO duality improves managerial accountability, as it makes it easier to charge the blame for poor performance, and thereby improved firm valuation.

The empirical evidence on the effect of $D B L S$ on market valuation is similarly mixed (Rechner and Dalton, 1991; Brickley et al., 1997; Weir et al., 2002). Rechner and Dalton (1991) investigate the link between DBLS and market valuation using 141 large US corporations from 1978 to 1983 . They report that companies with a DBLS consistently outperformed those with CEO duality. Similarly, Dahya et al. (1996) investigate whether the US stock market prefers companies to have a DBLS. Consistent with the evidence of Rechner and Dalton (1991), their results suggest that the market values firms with $D B L S$ more highly.

By contrast, other studies indicate that CEO duality rather impacts positively on firm valuation (Donaldson and Davis, 1991, 1994; Boyd, 1995; Kiel and Nicholson, 2003). For example, Donaldson and Davis (1991) examine the effects of CEO duality on shareholder returns in a sample of 321 US firms from 1985 to 1987. They report that companies with CEO duality have superior market valuation to those with $D B L S$. Similarly, Boyd (1995) investigates the association between CEO duality and market valuation in a sample of 192 American firms from 1980 to 1984. Consistent with the evidence of Donaldson and Davis (1991), he reports that firms with CEO duality consistently outperformed their counterparts with $D B L S$. Finally, using a sample of 348 Australian listed firms in 1996, Kiel and Nicholson (2003) report that CEO duality impacts positively on firm valuation.

A third stream of empirical papers suggests that role or CEO duality has no impact on market valuation. Using 25 Canadian firms from 1976 to 2000, Bozec (2005) reports that CEO duality has no impact on market valuation. This is consistent with the results of previous studies (Baliga et al., 1996; Brickley et al., 1997; Rhoades et al., 2001; Vafeas and Theodorou, 1998; Laing and Weir, 1999; Weir and Laing, 2000; Sanda et al., 2010), which suggest that CEO duality has no impact on market valuation.

Despite the conflicting empirical evidence, and as has been discussed in section 2, King II states explicitly that the positions of the chairman and the CEO should not be held by the same individual. Also, it states that the chairman must be independent, who bears the responsibility for the running of the board, while the CEO is responsible for the day-to-day running of the company's business. This suggests that King II recognises CEO duality as an undesirable development, while $D B L S$ is seen as a good CG practice. This indicates that King II expects $D B L S$ to have a positive effect on market valuation, and thus our main hypothesis is that:

$H_{l}$ : There is a statistically significant and positive relationship between $D B L S$ and market valuation.

\section{Data}

As a result of capital structure and regulatory reasons, 291 firms listed on the JSE as at 31/12/2007 from eight non-financial industries (basic materials, consumer goods, consumer services, health care, industrials, oil and gas, technology, and telecoms) were sampled. We employ CG and financial variables to examine the effect of $D B L S$ on 
market valuation. The CG variables were extracted from the annual reports of the sampled firms'. The annual reports were downloaded from the Perfect Information Database. The financial data were taken from Datastream. The firms in our final sample had to meet two criteria. First, a firm's complete 5-year annual reports from 2002 to 2006 inclusive are available. Second, the firm's corresponding financial data from 2003 to 2007 is also available. ${ }^{1}$ The criteria were set for several reasons. First, and following past studies (Rechner and Dalton, 1991; Bozec, 2005), the criteria helped in meeting the requirements for a balanced panel data analyses. Benefits for employing panel data include having both time series and cross-sectional properties, more degrees of freedom and less multicollinearities among variables (Gujarati, 2003; Wooldridge, 2010). Second, analysis of 5-year data with both cross-sectional and time series properties may help in determining whether the observed cross-sectional association between $D B L S$ and market valuation is robust over time, and thereby permits direct comparisons to be drawn with the results of past studies (Donaldson and Davis, 1991, 1994; Kiel and Nicholson, 2003). Applying the above criteria, the full data required is obtained for a total of 169 firms over 5 -firm years and 8 industries for our regression analysis.

\section{Empirical Analyses}

\subsection{Summary descriptive statistics}

Table 1 contains full definitions and summary statistics of all (market valuation, CG and control) variables that we employ in estimating our regressions. Table 1 indicates, for instance, that $Q$, which is our main (although as a robustness check, we use ROA and TSR as an alternative accounting and market based company valuation measures, respectively) market valuation proxy, is between a minimum of 0.72 and a maximum of 3.60 with a median of 1.34 . The DBLS ranges from a minimum of $0 \%$ to a maximum of $100 \%$ with an average of $84 \%$. The alternative market valuation variables (ROA and TSR), and the control variables (BIG4, CAPEX, CGCOM, CROSLIST, GOVOWN, and GROWTH), which we include in our regressions in order to control for potential omitted variables bias, also display wide spreads, implying that our sample has been adequately selected to obtain sufficient variability, and hence minimises any possibilities of sample selection bias.

\footnotetext{
${ }^{1}$ It takes time for board decisions to reflect in market value (Boyd, 1995; Ntim et al., 2012). Thus, to prevent endogenous link between DBLS and market valuation, we introduce a one year lag between DBLS and market valuation such that this year's market value depends on last year's CG structure, as specified in equation (1) below. The sample also starts from 2002 for two reasons. Firstly, King II came into operation in 2002, and secondly, data coverage in Perfect Information/DataStream on SA listed firms is very small until 2002.
} 
Table 1. Descriptive statistics of all variables for all 845 firm years

\begin{tabular}{|c|c|c|c|c|c|}
\hline Variable & Mean & Median & Std. Dev. & Maximum & Minimum \\
\hline \multicolumn{6}{|c|}{ Market valuation (dependent variables) } \\
\hline Q & 1.56 & 1.34 & 0.67 & 3.60 & 0.72 \\
\hline ROA & 0.11 & 0.12 & 0.14 & 0.38 & -0.19 \\
\hline TSR & 0.28 & 0.25 & 0.89 & 2.36 & -0.48 \\
\hline \multicolumn{6}{|c|}{ Dual board leadership structure (main independent variable) } \\
\hline DBLS & 0.84 & 1.00 & 0.37 & 1.00 & 0.00 \\
\hline \multicolumn{6}{|c|}{ Control variables } \\
\hline BIG4 & 0.73 & 1.00 & 0.44 & 1.00 & 0.00 \\
\hline CAPEX & 0.13 & 0.08 & 0.15 & 0.66 & 0.07 \\
\hline CGCOM & 0.32 & 0.00 & 0.47 & 1.00 & 0.00 \\
\hline CROSLIST & 0.22 & 0.00 & 0.41 & 1.00 & 0.00 \\
\hline GEAR & 0.32 & 0.19 & 0.31 & 0.78 & 0.01 \\
\hline GOVOWN & 0.38 & 0.00 & 0.49 & 1.00 & 0.00 \\
\hline GROWTH & 0.12 & 0.14 & 0.26 & 0.89 & -0.44 \\
\hline LNTA & 5.86 & 6.02 & 0.48 & 7.83 & 4.24 \\
\hline
\end{tabular}

Notes: Variables are defined as follows: Tobin's Q $(Q)$, defined as the ratio of total assets minus book value of equity plus market value of equity to total assets. Return on assets $(R O A)$, measured as the ratio of operating profit to total assets. Total shareholder returns $(T S R)$, calculated as annualised total shareholder returns made up of share price and dividends. Dual board leadership structure $(D B L S)$, defined as a dummy variable that takes the value of 1 if the positions of company chairperson and CEO are held by different persons, 0 otherwise. Audit firm size (BIG4), measured as a dummy variable that takes the value of 1 , if a firm is audited by a big four audit firm (PricewaterhouseCoopers, Deloitte \& Touché, Ernst \& Young, and KPMG), 0 otherwise. Capital expenditure (CAPEX), calculated as the ratio of total capital expenditure to total assets. Cross-listing (CROSLIST), measured as a dummy variable that takes the value of 1, if a firm is cross-listed to a foreign stock market, 0 otherwise. The presence of a corporate governance committee $(C G C O M)$, defined as a dummy variable that takes the value of 1 , if a firm has set up a corporate governance committee, 0 otherwise. Gearing (GEAR), calculated as the ratio of total debts to market value of equity. Government ownership $(G O V O W N)$, measured as a dummy variable that takes the value of 1, if government ownership is at least 5\%, 0 otherwise. Sales growth $(G R O W T H)$, calculated as the current year's sales minus last year's sales to last year's sales. Firm size (LNTA), measured as the natural log of total assets.

\subsection{Multivariate regression analyses}

Firms tend to vary in the challenges and opportunities that they experience over time. This can result in a scenario whereby $D B L S$ and $Q$ are jointly and dynamically influenced by company-level heterogeneities, such as managerial talent and corporate culture (Guest, 2009; Ntim, 2009), which simple OLS regressions may be unable to detect (Gujarati, 2003; Wooldridge, 2010), and thereby leading to spurious results. Thus, given the panel nature of our data and following past studies (Henry, 2008; Guest, 2009; Ntim et al., 2012), we run fixed-effects regressions in order to control for unobserved company-level differences. Therefore, we start our analysis with basic fixed-effects regression specified as follows:

$$
Q_{i t}=\alpha_{0}+\beta_{1} D B L S_{i t-1}+\sum_{i=1}^{n} \beta_{i} \text { CONTROLS }_{i t-1}+\delta_{i t-1}+\varepsilon_{i t-1}
$$

where: $Q$ is the main dependent variable, $D B L S$ is the main independent variable, CONTROLS refers to the control variables, including BIG4, CAPEX, CGCOM, CROSLIST, GOVOWN, GROWTH, INDUST and YD, and $\delta$ refers to the company-level 
fixed-effects, consisting of a vector of 168 year dummies to represent the 169 sampled companies.

Table 2 contains the results of fixed-effects regressions of $D B L S$ on $Q$. First, to examine whether the $D B L S$ is associated with $Q$, we regress $Q$ on $D B L S$ alone without the control variables using equation (1). Positive, but statistically insignificant impact of $D B L S$ on $Q$ is noticeable in Model 1 of Table 2. However, the coefficient on the constant term in Model 1 of Table 2 is statistically significant and appears to indicate that there may be omitted variables bias. Thus, we include the control variables in Model 2 so as to take into consideration potential omitted variables bias. Observably, the coefficient on $D B L S$ remains positive, but statistically insignificant in Model 2 of Table 2, and thereby failing to provide support for $\mathrm{Hl}$ and the recommendations of King II, but consistent with the findings of prior studies (Weir and Laing, 2000; Sanda et al., 2010) that suggest that $D B L S$ has no impact on market valuation.

Second, and given that a high proportion (see Table 1) of our sample have a DBLS, its insignificance may be due to the limited variability in the sample. Therefore, to ascertain that our results are driven by this phenomenon, we split the sample into two sub-samples, firms with: $D B L S$ with non-independent chairperson (DBLSWNIC) and (ii) $D B L S$ with independent chairperson (DBLSWIC). As King II sets stricter tests for independent nonexecutive directors than non-executive directors, such as not having professional, ownership, employment, family, supplier and customer connections (see King Report, 2002, para. 2.4), independent chairpersons can be expected to be more effective at monitoring and disciplining unruly CEOs, and thus, a higher market valuation for firms with $D B L S W I C$ than those with $D B L S W N I C$. We test this proposition by re-regressing equation (1) by replacing $D B L S$ with: (i) $D B L S W N I C$ and (ii) $D B L S W I C$, one at a time. Consistent with our prediction, positive, but statistically insignificant effect of $D B L S W N I C^{2}$ on $Q$ is noticeable in Model 3 of Table 2, whilst the coefficient on DBLSWIC in Models 4 and 5 are both positive and statistically significant, and thereby providing support for $H 1$. The evidence also implies that it is the independence of the chairperson rather than the mere split of roles that can have a significant positive impact on market valuation.

Theoretically, our results are consistent with agency theory that indicates that corporate boards with independent $D B L S$ have increased capacity to effectively advise, monitor and discipline top management, and thereby enhancing market valuation (Lipton and Lorsch, 1992; Jensen, 1993). Our evidence also provides support for both the recommendations of King II and the findings of previous studies (Rechner and Dalton, 1991; Dahya et al., 1996) that report a positive association between $D B L S$ and market valuation, but inconsistent with those that either report a negative (Boyd, 1995; Kiel and Nicholson, 2003) or no (Baliga et al., 1996; Bozec, 2005) association.

\footnotetext{
${ }^{2}$ We first re-regressed $D B L S W N I C$ on $Q$ alone with the results showing a similar positive, but statistically insignificant coefficient.
} 
Table 2. Fixed-effects regressions of dual board leadership structure on market valuation

\begin{tabular}{|c|c|c|c|c|c|c|c|c|}
\hline Dependent variable & $\overline{\mathbf{Q}}$ & $\overline{\mathbf{Q}}$ & $\overline{\mathbf{Q}}$ & $\bar{Q}$ & $\bar{Q}$ & $\overline{\mathrm{ROA}}$ & $\overline{\text { TSR }}$ & 2SLS (Q) \\
\hline Adjusted $R^{2}$ & 0.015 & 0.176 & 0.184 & 0.028 & 0.279 & 0.285 & 0.310 & 0.353 \\
\hline$F$-value & $2.943^{\text {**** }}$ & $3.978^{* * *}$ & $4.237^{* * * *}$ & $4.652^{* * * *}$ & $5.840^{* * *}$ & $7.869^{* * * *}$ & $8.165^{* * *}$ & $8.634^{* * * *}$ \\
\hline$(N)$ & $(845)$ & (845) & (469) & (376) & $(376)$ & (376) & (376) & (376) \\
\hline Constant & $\begin{array}{c}1.070 \\
(0.024)^{* *}\end{array}$ & $\begin{array}{c}1.490 \\
(0.000)^{* * * *}\end{array}$ & $\begin{array}{l}1.514 \\
(0.000)^{* * * *}\end{array}$ & $\begin{array}{l}1.310 \\
(0.000)^{* * * *}\end{array}$ & $\begin{array}{l}1.648 \\
(0.000)^{* * * *}\end{array}$ & $\begin{array}{l}-0.358 \\
(0.450)\end{array}$ & $\begin{array}{l}2.834 \\
(0.000)^{* * * *}\end{array}$ & $\begin{array}{l}2.975 \\
(0.000)^{* * * *}\end{array}$ \\
\hline Independent variable & (1) & (2) & (3) & (4) & (5) & (6) & (7) & (8) \\
\hline DBLS & $\begin{array}{c}0.004 \\
(0.892)\end{array}$ & $\begin{array}{c}0.002 \\
(0.910)\end{array}$ & - & - & $\begin{array}{l}- \\
-\end{array}$ & - & - & $\begin{array}{l}- \\
-\end{array}$ \\
\hline DBLSWNIC & - & - & $\begin{array}{c}0.003 \\
(0.896)\end{array}$ & - & - & - & - & - \\
\hline DBLSWIC & - & - & - & $\begin{array}{l}0.075 \\
(0.000)^{* * * *}\end{array}$ & $\begin{array}{l}0.068 \\
(0.049)^{* * *}\end{array}$ & $\begin{array}{c}0.649 \\
(0.000)^{\text {**** }}\end{array}$ & $\begin{array}{c}0.836 \\
(0.000)\end{array}$ & - \\
\hline PRE_DBLSWIC & $\begin{array}{l}- \\
-\end{array}$ & - & - & - & $\begin{array}{l}- \\
-\end{array}$ & - & $\begin{array}{l}- \\
-\end{array}$ & $\begin{array}{l}0.080 \\
(0.000)^{* * * *}\end{array}$ \\
\hline Control variables & & & & & & & & \\
\hline BIG4 & $\begin{array}{l}- \\
-\end{array}$ & $\begin{array}{l}0.146 \\
(0.012)^{* * *}\end{array}$ & $\begin{array}{l}0.144 \\
(0.015)^{* * *}\end{array}$ & $\begin{array}{l}- \\
-\end{array}$ & $\begin{array}{l}0.148 \\
(0.019)^{* * * *}\end{array}$ & $\begin{array}{c}0.833 \\
(0.012)^{* *}\end{array}$ & $\begin{array}{l}4.254 \\
(0.029)^{* *}\end{array}$ & $\begin{array}{l}0.198 \\
(0.000)^{* * * *}\end{array}$ \\
\hline CAPEX & $\begin{array}{l}- \\
-\end{array}$ & $\begin{array}{l}-0.010 \\
(0.000)^{\text {**** }}\end{array}$ & $\begin{array}{l}-0.009 \\
(0.000)^{* * * *}\end{array}$ & $\begin{array}{l}- \\
-\end{array}$ & $\begin{array}{l}-0.007 \\
(0.000)^{* * *}\end{array}$ & $\begin{array}{l}-0.048 \\
(0.011)^{* *}\end{array}$ & $\begin{array}{l}-0.120 \\
(0.080)^{*}\end{array}$ & $\begin{array}{l}-0.016 \\
(0.000)^{* * * *}\end{array}$ \\
\hline CGCOM & - & $\begin{array}{l}0.216 \\
(0.000)^{* * * *}\end{array}$ & $\begin{array}{l}0.219 \\
(0.000)^{* * * *}\end{array}$ & - & $\begin{array}{l}0.210 \\
(0.000)^{* * * *}\end{array}$ & $\begin{array}{l}1.640 \\
(0.020)^{* *}\end{array}$ & $\begin{array}{l}1.749 \\
(0.030)^{* *}\end{array}$ & $\begin{array}{l}0.220 \\
(0.000)^{* * * *}\end{array}$ \\
\hline CROSLIST & - & $\begin{array}{c}0.230 \\
(0.038)^{* * *}\end{array}$ & $\begin{array}{c}0.228 \\
(0.040)^{* * *}\end{array}$ & - & $\begin{array}{l}0.235 \\
(0.031)^{* * *}\end{array}$ & $\begin{array}{l}2.294 \\
(0.040)^{* *}\end{array}$ & $\begin{array}{l}2.612 \\
(0.004)^{* * * *}\end{array}$ & $\begin{array}{c}0.280 \\
(0.000)^{* * * *}\end{array}$ \\
\hline GEAR & - & $\begin{array}{l}-0.012 \\
(0.000)^{* * * *}\end{array}$ & $\begin{array}{l}-0011 \\
(0.000)^{* * *}\end{array}$ & $\begin{array}{l}- \\
-\end{array}$ & $\begin{array}{l}-0.016 \\
(0.000)^{* * *}\end{array}$ & $\begin{array}{l}-0.168 \\
(0.000)^{* * * *}\end{array}$ & $\begin{array}{l}-0.386 \\
(0.000)^{* * * *}\end{array}$ & $\begin{array}{l}-0.022 \\
(0.000)^{* * *}\end{array}$ \\
\hline GOVOWN & $\begin{array}{l}- \\
-\end{array}$ & $\begin{array}{c}0.116 \\
(0.009)^{* * * *}\end{array}$ & $\begin{array}{c}0.110 \\
(0.015)^{* *}\end{array}$ & $\begin{array}{l}- \\
-\end{array}$ & $\begin{array}{l}0.117 \\
(0.020)^{* * *}\end{array}$ & $\begin{array}{l}7.060 \\
(0.000)^{\text {**** }}\end{array}$ & $\begin{array}{c}6.850 \\
(0.000)^{* * * *}\end{array}$ & $\begin{array}{c}0.365 \\
(0.000)^{* * * *}\end{array}$ \\
\hline GROWTH & - & $\begin{array}{l}0.178 \\
(0.000)^{\text {**** }}\end{array}$ & $\begin{array}{l}0.174 \\
(0.000)^{* * * *}\end{array}$ & $\begin{array}{l}- \\
-\end{array}$ & $\begin{array}{l}0.183 \\
(0.000)^{* * * *}\end{array}$ & $\begin{array}{l}0.253 \\
(0.000)^{\text {***** }}\end{array}$ & $\begin{array}{l}0.153 \\
(0.000)^{* * *}\end{array}$ & $\begin{array}{l}0.186 \\
(0.000)^{* * * *}\end{array}$ \\
\hline LNTA & - & $\begin{array}{l}-0.215 \\
(0.000)^{* * * *}\end{array}$ & $\begin{array}{l}-0.210 \\
(0.000)^{* * * *}\end{array}$ & $\begin{array}{l}- \\
-\end{array}$ & $\begin{array}{l}-0.209 \\
(0.000)^{* * * *}\end{array}$ & $\begin{array}{l}-2.786 \\
(0.000)^{\text {***** }}\end{array}$ & $\begin{array}{l}-6.529 \\
(0.000)^{\text {**** }}\end{array}$ & $\begin{array}{l}-0.292 \\
(0.000)^{* * * *}\end{array}$ \\
\hline INDUST & - & Included & Included & - & Included & Included & Included & Included \\
\hline YD & - & Included & Included & - & Included & Included & Included & Included \\
\hline
\end{tabular}




\subsection{Robustness analyses}

Our fixed-effects regressions so far do not take into consideration alternative market valuation proxiess and other potential endogeneities, suggesting that the positive impact of $D B L S W I C$ on $Q$, for example, may be spurious. In this subsection, we examine how robust our results are to the use of alternative market valuation measures and the presence of endogeneities.

First, we investigate the robustness of our results to two alternative market valuation proxies that we have data on: return on assets ( $R O A$ - an accounting based measure) and total share returns (TSR - a market based proxy). Models 6 and 7 of Table 2 contain findings based on using $R O A$ and $T S R$, respectively, instead of $Q$. Statistically significant and positive effect of DBLSWIC on ROA and TSR in models 6 and 7 of Table 2, respectively, is noticeable, and thereby suggesting that our findings are robust when an accounting (ROA) or a market (TSR) based proxy of valuation is utilised instead of $Q$.

Second, to account for potential endogeneities that may be caused by omitted variable bias, we employ the widely used two-stage least squares $(2 S L S)$ methodology (Beiner et al., 2006; Henry, 2008). However, to ensure that the 2SLS methodology is appropriate, and following Beiner et al. (2006), we first conduct Durbin-Wu-Hausman exogeneity test (see Beiner et al., 2006: p.267) to test for the presence of an endogenous association between $Q$ and $D B L S W I C$. Applied to equation (1), the test does not accept the null hypothesis of no endogeneity, and therefore, we conclude that the $2 S L S$ methodology may be ideal and that our fixed-effects findings may be spurious. In the first stage, we conjecture that the DBLSWIC will be influenced by all the control variables contained in equation (1). In the second stage, we utilise the predicted part of the DBLSWIC (PRE_DBLSWIC) as an instrument for DBLSWIC and re-regress equation (1) on as follows:

$$
Q_{i t}=\alpha_{0}+\hat{\beta}_{1} D B L S W I C_{i t}+\sum_{i=1}^{n} \beta_{i} \text { CONTROLS }_{i t}+\delta_{i t}+\varepsilon_{i t}
$$

where everything remains unchanged as specified in equation (1) except that we employ the predicted DBLSWIC (PRE_DBLSWIC) from the first-stage estimation as an instrument for the DBLSWIC. The coefficient on the PRE_DBLSWIC in Model 8 of Table 2 is positive and statistically significant, and thereby suggesting that our evidence of a positive effect of $D B L S W I C$ on $Q$ is robust to potential endogeneities that may arise from omitted variables. Overall, the robustness analyses suggest that our findings are not sensitive to different types of endogeneities and market valuation proxies.

\section{Concluding Remarks}

This paper examines the link between dual board leadership structure $(D B L S)$ and market valuation using a sample 169 South African (SA) listed firms from 2002 to 2007. This coincides with a period during which the SA authorities embarked on corporate governance policy reforms, which focused mainly on enhancing board independence and monitoring power in the form of the 1994 (King I) and 2002 (King II) King Reports. We find a significant positive link between $D B L S$ and market valuation, but only in firms with independent chairpersons, implying that the market values firms with independent $D B L S$ more highly. Our evidence provides support for both the recommendations of King II and the findings of previous studies (Rechner and Dalton, 
1991; Dahya et al., 1996) that report a positive association between $D B L S$ and market valuation, but inconsistent with those that either report a negative (Boyd, 1995; Kiel and Nicholson, 2003) or no (Baliga et al., 1996; Bozec, 2005) association. The findings are robust across a number of econometric models that control for different types of market valuation proxies and endogeneity problems. Theoretically, the findings are consistent with agency theory, which suggests that independent $D B L S$ increases the capacity of the board to effectively advise, monitor and discipline management, and thereby improving market valuation. Our evidence also has important regulatory and policy implications. The evidence that the market values only firms with independent $D B L S$ implies that the SA authorities should focus more on encouraging firms to go beyond merely having $D B L S$ to having independent $D B L S$, as recommended by King II.

Acknowledgements. The author gratefully acknowledges useful and timely comments by the Editor, Francisco J. Delgado, Associate Editor, Ruben Arrondo-Garcia and an anonymous reviewer.

\section{References}

Baliga, R.B., Moyer, C.R. and Rao, R.B. (1996) CEO duality and firm financial performance, Strategic Management Journal, 17, 41-53.

Beiner, S., Drobetz, W., Schmid, M.M., and Zimmermann, H. (2006) An integrated framework of corporate governance and firm valuation. European Financial Management, 12, 249-283.

Boyd, B.K. (1995) CEO duality and firm performance: a contingency model, Strategic Management Journal, 16, 301-312.

Bozec, R. (2005) Boards of directors, market discipline and firm performance, Journal of Business Finance \& Accounting, 32(9-10), 1921-1960.

Brickley, J.A., Coles, L. and Jarrell, G. (1997) Corporate leadership structure: on the separation of the positions of CEO and chairman of the board, Journal of Corporate Finance, 3, 189-220.

Dahya, J., Lonie, A.A. and Power, D.M. (1996) The Case for separating the roles of chairman and CEO: an analysis of stock market and accounting data, Corporate Governance: An International Review, 4(2), 71-77.

Donaldson, L. and Davis, (1991) Stewardship theory or agency theory: CEO governance and shareholder returns, Australian Journal of Management, 16(1), 49-64.

Donaldson, L. and Davis, J.H. (1994) Boards and company performance - research challenges the conventional wisdom, Corporate Governance: An International Review, 2, 151-160.

Guest, P.M., (2009) The impact of board size on firm performance: evidence from the UK, European Journal of Finance, 15, 385-404.

Gujarati, D.N. (2003) Basic econometrics. McGraw-Hill: New York.

Henry, D. (2008) Corporate governance structure and the valuation of Australian firms: is there value in ticking the boxes. Journal of Business Finance \& Accounting, 35, 912-942.

Jensen, M.C. (1993) The modern industrial revolution, exit, and the failure of internal control systems, Journal of Finance, 48, 831-880.

Kiel, G.C. and Nicholson, G.J. (2003) Board composition and corporate performance: how the Austrian experience informs contrasting theories of corporate governance, Corporate Governance: An International Review, 11(3), 189-205. 
King Committee. (1994 \& 2002) King reports on corporate governance for South Africa. Institute of Directors, Johannesburg.

Laing, D. and Weir, C.M. (1999) Governance structures, size and corporate performance in UK firms, Management Decisions, 37(5), 457-464.

Lipton, M., and Lorsch, J. (1992) A modest proposal for improved corporate governance, Business Lawyer, 48, 59-77.

Ntim C.G., Opong K.K., and Danbolt, J. (2012) The value relevance of shareholder versus stakeholder corporate governance disclosure policy reforms in South Africa. Corporate Governance: An International Review, 20(1), 84-105.

Ntim C.G., Opong K.K., Danbolt, J., and Thomas, D.A. (2011) Voluntary corporate governance disclosures by post-apartheid South African corporations. Journal of Applied Accounting Research, forthcoming.

Ntim, C.G. (2011) The King reports, independent non-executive directors and firm valuation on the Johannesburg stock exchange. Corporate Ownership and Control, 9(1), 428-440.

Ntim, C.G. (2012) An integrated corporate governance framework and financial performance in South African listed corporations. South African Journal of Economics, forthcoming.

Ntim, C.G. and Osei, K.A. (2011) The impact of corporate board meetings on corporate performance in South Africa. African Review of Economics and Finance, 2(2), 83103.

Ntim, C.G., (2009) Internal corporate governance and firm financial performance evidence from South African listed firms. PhD thesis, University of Glasgow.

Petersen, M.A. (2009) Estimating standard errors in finance panel data sets: comparing approaches. Review of Financial Studies, 22, 435-480.

Rechner, P.L. and Dalton, D.R. (1991) CEO duality and organizational performance: a longitudinal analysis, Strategic Management Journal, 12(2), 155-160.

Rhoades, D.L., Rechner, P.L. and Sudramurthy, C. (2001) A meta-analysis of board directorship structure and financial performance: are "two heads better than one? Corporate Governance: An International Review, 9, 311-319.

Sanda, A., Mikailu, A.S. and Garba, T. (2010) Corporate governance mechanisms and firm financial performance in Nigeria, Afro-Asian Journal of Finance and Accounting, 2(1), 22-39.

Vafeas, N. and Theodorou, E. (1998) The relationship between board structure and firm performance in the UK, British Accounting Review, 30, 383-407.

Weir C., Laing, D. and McKnight, P.J. (2002) Internal and external governance mechanisms: their impact on the performance of large UK public companies', Journal of Business Finance and Accounting, 29(5), 579-611.

Weir, C. and Laing, D. (2000) The performance-governance relationship: the effects of Cadbury compliance on UK quoted companies, Journal of Management and Governance, 4, 265-281.

Wooldridge, J.M. (2010) Econometric analysis of cross section and panel data. MIT Press: Massachusetts. 